\title{
Effect of different ammonia sources on aceticlastic and hydrogenotrophic methanogens
}

Tian, Hailin; Fotidis, Ioannis; Kissas , Konstantinos ; Angelidaki, Irini

Published in:

Bioresource Technology

Link to article, DOI:

10.1016/j.biortech.2017.11.081

Publication date:

2018

Document Version

Peer reviewed version

Link back to DTU Orbit

Citation (APA):

Tian, H., Fotidis, I., Kissas , K., \& Angelidaki, I. (2018). Effect of different ammonia sources on aceticlastic and hydrogenotrophic methanogens. Bioresource Technology, 250, 390-397.

https://doi.org/10.1016/j.biortech.2017.11.081

\section{General rights}

Copyright and moral rights for the publications made accessible in the public portal are retained by the authors and/or other copyright owners and it is a condition of accessing publications that users recognise and abide by the legal requirements associated with these rights.

- Users may download and print one copy of any publication from the public portal for the purpose of private study or research.

- You may not further distribute the material or use it for any profit-making activity or commercial gain

- You may freely distribute the URL identifying the publication in the public portal

If you believe that this document breaches copyright please contact us providing details, and we will remove access to the work immediately and investigate your claim. 


\section{Accepted Manuscript}

Effect of different ammonia sources on aceticlastic and hydrogenotrophic methanogens

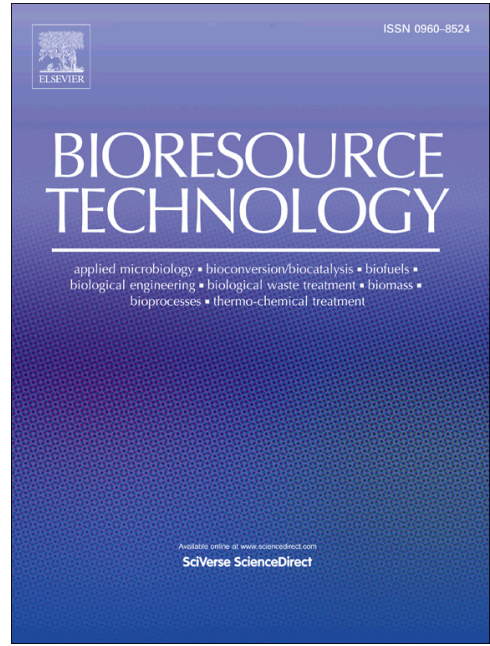

To appear in: $\quad$ Bioresource Technology

Received Date: $\quad 6$ November 2017

Revised Date: $\quad 22$ November 2017

Accepted Date: $\quad 23$ November 2017

Please cite this article as: Tian, H., Fotidis, I.A., Kissas, K., Angelidaki, I., Effect of different ammonia sources on aceticlastic and hydrogenotrophic methanogens, Bioresource Technology (2017), doi: https://doi.org/10.1016/ j.biortech.2017.11.081

This is a PDF file of an unedited manuscript that has been accepted for publication. As a service to our customers we are providing this early version of the manuscript. The manuscript will undergo copyediting, typesetting, and review of the resulting proof before it is published in its final form. Please note that during the production process errors may be discovered which could affect the content, and all legal disclaimers that apply to the journal pertain. 


\section{Effect of different ammonia sources on aceticlastic and}

\section{2 hydrogenotrophic methanogens}

3

4 Hailin Tian, Ioannis A. Fotidis*, Konstantinos Kissas, Irini Angelidaki 5

6 Department of Environmental Engineering, Technical University of Denmark, Bygningstorvet 7 Bygning 115, DK-2800 Kgs. Lyngby, DK

8

9

$10 *$ Corresponding Author: Ioannis A. Fotidis, Department of Environmental Engineering,

11 Technical University of Denmark, Bygningstorvet Bygning 115, DK-2800 Kgs. Lyngby,

12 Denmark, Phone: (+45) 45251418; Fax: (+45) 45933850; e-mail: ioanf@env.dtu.dk 


\section{Abstract}

Ammonium chloride $\left(\mathrm{NH}_{4} \mathrm{Cl}\right)$ was usually used as a model ammonia source to simulate ammonia inhibition during anaerobic digestion (AD) of nitrogen-rich feedstocks. However, ammonia in $\mathrm{AD}$ originates mainly from degradation of proteins, urea and nucleic acids, which is distinct from $\mathrm{NH}_{4} \mathrm{Cl}$. Thus, in this study, the inhibitory effect of a "natural" ammonia source (urea) and $\mathrm{NH}_{4} \mathrm{Cl}$, on four pure methanogenic strains (aceticlastic: Methanosarcina thermophila, Methanosarcina barkeri; hydrogenotrophic: Methanoculleus bourgensis, Methanoculleus thermophilus $)$, was assessed under mesophilic $\left(37^{\circ} \mathrm{C}\right)$ and thermophilic $\left(55^{\circ} \mathrm{C}\right)$ conditions. The results showed that urea hydrolysis increased $\mathrm{pH}$ significantly to unsuitable levels for methanogenic growth, while $\mathrm{NH}_{4} \mathrm{Cl}$ had a negligible effect on $\mathrm{pH}$. After adjusting initial $\mathrm{pH}$ to 7 and 8 , urea was significantly stronger inhibitor with longer lag phases to methanogenesis compared to $\mathrm{NH}_{4} \mathrm{Cl}$. Overall, urea seems to be more toxic on both aceticlastic and hydrogenotrophic methanogens compared to $\mathrm{NH}_{4} \mathrm{Cl}$ under the same total and free ammonia levels.

\section{Keywords}

Ammonia inhibition; Ammonium chloride; Anaerobic digestion; Pure strain; Urea. 


\section{Introduction}

Biogas (a mixture of $\mathrm{CH}_{4}$ and $\mathrm{CO}_{2}$ ) is an attractive renewable energy (Holm-Nielsen et al., 2009), which is formed during anaerobic digestion (AD) of different biomasses. As one of the most promising and widely used green technologies, $\mathrm{AD}$ is a complex biological process with different microorganisms involved, which can reduce the waste pollution and offset part of the energy usage (Chynoweth et al., 2001). However, it is reported that some potential substrates are toxic to AD process by inhibiting the microorganisms' activity (Chen et al., 2008). Among these substrates, nitrogen-rich substrates stand out, due to the ammonia formation during their degradation. A low ammonia concentration $\left(<200 \mathrm{mg} \mathrm{NH}_{4}{ }^{+}-\mathrm{N} \mathrm{L}^{-1}\right)$ is beneficial to AD process; nevertheless, relatively high ammonia levels (> $2000 \mathrm{mg} \mathrm{NH}_{4}{ }^{+}-\mathrm{N} \mathrm{L}^{-1}$ ) would inhibit AD, causing instability and even process failure (Liu and Sung, 2002). Total ammonia (TAN) in aqueous solutions is the sum of ammonium ions $\left(\mathrm{NH}_{4}{ }^{+}\right)$and free ammonia $\left(\mathrm{FAN}, \mathrm{NH}_{3}\right)$. The $\mathrm{NH}_{4}{ }^{+}$and $\mathrm{NH}_{3}$ exist in an equilibrium (Eq. (1)), which is affected by the temperature and the $\mathrm{pH}$ (Emerson et al., 1975). Specifically, FAN, which was suggested to be the most toxic form of ammonia (Massé et al., 2014), increases along with temperature and pH.

Methanogenesis, the last step of AD process, is more sensitive to ammonia than hydrolysis, acidogenesis and acetogenesis steps (Yenigün and Demirel, 2013). Furthermore, in most of the studies, hydrogenotrophic methanogens were reported to be more robust to ammonia toxicity than aceticlastic methanogens (Schnürer et al., 1999; Werner et al., 2014; Dai et al., 2017). However, controversial results can also be found (Calli et al., 2005; Karakashev et al., 2005).

Considering ammonia inhibition is such a serious and highly debated topic, a great number of studies focusing on the impact of ammonia levels and on inhibition mechanism have been conducted in different reactor types (Angelidaki and Ahring, 1993; Sung and Liu, 2003; Cuetos et al., 2008; Wang et al., 2015; Chen et al., 2016). As a result, it is reviewed that 
6

$50 \%$ inhibition was caused by TAN concentrations ranging from 1700 to $14000 \mathrm{mg} \mathrm{NH}_{4}{ }^{+}-\mathrm{N}$

$\mathrm{L}^{-1}$ depending on different experimental conditions (Chen et al., 2008). However, in most of the aforementioned studies, ammonium chloride $\left(\mathrm{NH}_{4} \mathrm{Cl}\right)$ was used as the inhibitor (ammonia source), and only few experiments can be found using other ammonia sources (Sterling et al., 2001; Westerholm et al., 2012; Dai et al., 2017). As a salt, $\mathrm{NH}_{4} \mathrm{Cl}$ can dissociate immediately after addition into aqueous solutions and release chloride anions and ammonium cations, as shown in Eq. (2). However, since chloride anions could also be a potential inhibitor to AD process (Riffat and Krongthamchat, 2006; Viana et al., 2012), it is difficult to differentiate if the inhibitory effect only comes from ammonia. Moreover, in the real AD applications, when nitrogen-rich substrates are used as feedstocks, ammonia is usually formed by the degradation of proteins, urea and nucleic acids (Rajagopal et al., 2013). Furthermore, urea is the main part of animal urine besides water; thus abounds in animal slurry (e.g. poultry, mink pig, cattle) and slaughterhouse wastewater (Møller et al., 2004). Without urease, which is the enzyme that catalyses urea hydrolysis, urea in aqueous solutions has a negligible reaction rate constant of $6.3 * 10^{-9} \mathrm{~s}^{-1}$ and a half-life of 3.5 years (Krajewska, 2009). However, urease can be synthesized by different microorganisms, including some bacteria involved in AD process, which can accelerate the hydrolysis of urea by nearly $10^{14}$ times faster than the uncatalysed decomposition (Ciurli et al., 1999). As shown in Eq. (3), the direct hydrolysed product of urea is the most toxic ammonia form (i.e. FAN) (Zimmer, 2000). In addition, hydrolysis of urea causes sudden $\mathrm{pH}$ increase, which could negatively affect the AD process (Mobley et al., 1995; Ciurli et al., 1999).

$\mathrm{NH}_{3}$ (aq.) $+\mathrm{H}_{2} \mathrm{O}$ (1.) $\leftrightarrow \mathrm{NH}_{4}^{+}$(aq.) $+\mathrm{OH}^{-}$(aq.)

$\mathrm{NH}_{4} \mathrm{Cl}$ (s.) $+\mathrm{H}_{2} \mathrm{O}($ l. $) \rightarrow \mathrm{NH}_{4}^{+}$(aq.) $+\mathrm{Cl}^{-}$(aq.)

$\mathrm{CO}\left(\mathrm{NH}_{2}\right)_{2}$ (s.) $+2 \mathrm{H}_{2} \mathrm{O}$ (1.) $\stackrel{\text { urease }}{\longrightarrow} 2 \mathrm{NH}_{3}$ (aq.) $+\mathrm{H}_{2} \mathrm{CO}_{3}$ (aq.) 
Thus, in order to separate the inhibition only caused by ammonia and simulate this process closer to realistic conditions, urea was used as ammonia source in reactors fed with cattle manure (Sterling et al., 2001). However, among the limited studies using urea as ammonia source, nothing can be found about its effect on methanogens. Considering

\subsection{Pure strains, ammonia sources and enzyme} $\mathrm{pH}$.

\section{Materials and methods}

methanogenesis is the most sensitive step of AD process (Chen et al., 2008), it is important to understand the urea effect on different methanogens. In addition, to date, there are no studies assessing simultaneously the effect of $\mathrm{NH}_{4} \mathrm{Cl}$ and urea on methanogenic archaea.

Therefore, the main aim of the present study was to investigate the effect of two different ammonia sources on four pure methanogenic strains (i.e. two aceticlastic and two hydrogenotrophic), under mesophilic $\left(37^{\circ} \mathrm{C}\right)$ and thermophilic $\left(55^{\circ} \mathrm{C}\right)$ conditions. To fulfil this aim, firstly, the effect on $\mathrm{pH}$ caused by the $\mathrm{NH}_{4} \mathrm{Cl}$ dissociation and urea hydrolysis in $\mathrm{AD}$ batch reactors was investigated. Secondly, under controlled $\mathrm{pH}$ conditions (i.e. 7 and 8), five different TAN levels (i.e. ten different FAN levels) were applied on each pure methanogenic strain to evaluate the effect of the two ammonia sources on the cultures, independently of the

Four pure methanogenic strains (aceticlastic: Methanosarcina thermophila TM-1 DSM No.1825 and Methanosarcina barkeri MS DSM No. 800; hydrogenotrophic: Methanoculleus thermophilus CR-1 DSM No. 2373 and Methanoculleus bourgensis $\mathrm{MS}^{\mathrm{T}}{ }^{\mathrm{DS} M}$ No. 3045) were purchased from DSMZ GmbH Company and used throughout the study. $M$. thermophila and M. thermophilus are thermophilic, while $M$. barkeri and $M$. bourgensis are mesophilic methanogens. All the pure strains were cultivated in the specific growth media suggested by 
DSMZ GmbH Company. Specifically, the growth media used were medium 120 (DSMZ,

105

106

107

108

109

110

111

112

113

114

115

116 2014a) for M. thermophila, medium 120a (DSMZ, 2014b) for M. barkeri, medium 141

(DSMZ, 2017) for M. thermophilus, and medium 332 (DSMZ, 2014c) for M. bourgensis. The carbon sources that were used for each strain were: acetate and methanol for $M$. thermophila; $\mathrm{CO}_{2}$ for M. thermophilus; methanol for M. barkeri; and formate and $\mathrm{CO}_{2}$ for M. bourgensis. Ammonium chloride (Sigma-Aldrich, CAS no. 12125-02-9) and urea (Sigma-Aldrich, CAS no. 57-13-6) were used as ammonia sources for the main experiment. Urease (Type IX, Sigma-Aldrich, CAS no. 9002-13-5) from Canavalia ensiformis (jack bean) seeds was used as enzyme to hydrolyse urea. A buffer solution consisted of $0.2 \mathrm{M}$ sodium phosphate with $\mathrm{pH}$ 7.3 was prepared for the dissolution of the enzyme before use.

\subsection{Experimental setup}

Two batch experimental assays were performed in this study to investigate the effect of different ammonia sources on $\mathrm{pH}$ fluctuation of the reactors (Assay I) and on the methanogenic process efficiency (Assay II). Before the experiments started, the pure strains, bought from DSMZ (DSMZ GmbH Company, Germany), were cultivated according to its corresponding cultivation protocols (DSMZ, 2014c; DSMZ, 2014b; DSMZ, 2014a; DSMZ, 2017). After several (4-6) generations, the cultures were used as inocula in the two experimental assays of the current study with a 20/80 (v/v) inoculum to medium ratio throughout the experiment. Meanwhile, urease was added to all batch reactors regardless of the ammonia source. Furthermore, all the experiments were conducted in triplicates.

\subsubsection{Assay I: Effect on pH}

All the pure strains were tested under different ammonia levels as depicted in Table 1. Serum vials were used with 40 and $118 \mathrm{~mL}$ working and total volume, respectively. After adding the corresponding medium, each vial was closed with butyl rubber stopper and sealed with aluminium caps, then flushed with a mixture gas of $\mathrm{N}_{2} / \mathrm{CO}_{2}(80 / 20, \mathrm{v} / \mathrm{v})$ to create anoxic 
129

130

131

132

133

conditions and autoclaved to provide sterile conditions. Other solutions that could not be autoclaved according to the instructions $\left(\mathrm{NaHCO}_{3}, \mathrm{Na}_{2} \mathrm{CO}_{3}\right.$, Vitamin, Methanol, L-cysteine$\mathrm{HCl} \cdot \mathrm{H}_{2} \mathrm{O}$ and $\mathrm{Na}_{2} \mathrm{~S} \cdot 9 \mathrm{H}_{2} \mathrm{O}$ ) were introduced by using sterilized, $0.2 \mu \mathrm{m}$ pore size, Minisart ${ }^{\circledR}$ NML Syringe Filters (Sartorius Stedim Biotech GmbH, Germany) to avoid any contamination. $\mathrm{Na}_{2} \mathrm{~S} \cdot 9 \mathrm{H}_{2} \mathrm{O}$ solution was added as a reducing agent after inoculation. In addition, pure $\mathrm{H}_{2}$ $(62.4 \mathrm{~mL})$ and $\mathrm{CO}_{2}(15.6 \mathrm{~mL})$ were added in the headspace of the batch reactors of the hydrogenotrophic strains. Afterwards, all the batch reactors were incubated at their corresponding temperatures $\left(37 \pm 1^{\circ} \mathrm{C}\right.$ for mesophilic and $55 \pm 1^{\circ} \mathrm{C}$ for thermophilic). The $\mathrm{pH}$ was measured after the urea hydrolysis finished (approximately 20 hours after the incubation stated based on preliminary hydrolysis test, and the details were provided in the E-supplement file).

\subsubsection{Assay II: Effect on methanogenesis}

In this assay, two different ammonia sources with five different TAN and ten different FAN levels (as shown in Table 2) were tested on all the methanogens. For all the strains, serum vials with $40 \mathrm{~mL}$ working volume was used, while total volume of $245 \mathrm{~mL}$ was used for M. thermophila and M. thermophilus cultivation, and total volume of $118 \mathrm{~mL}$ was used for $M$. barkeri and M. bourgensis. The reactors were closed with rubber stoppers, sealed with aluminium caps, and flushed with a mixture $\mathrm{N}_{2} / \mathrm{CO}_{2}$ gas $(80 / 20, \mathrm{v} / \mathrm{v})$ after the addition of medium. All the reactors containing medium were autoclaved before inoculation. Chemical solutions, which could not be autoclaved, were added through sterilized filters afterwards. In addition, for hydrogenotrophic $M$. thermophilus and $M$. barkeri, $\mathrm{H}_{2} / \mathrm{CO}_{2}(80 / 20$, v/v) mixture gas was injected into the headspace of the reactor to form 1 bar overpressure. Furthermore, a $\mathrm{pH}$ adjustment strategy (the details were provided in the E-supplement file) was performed to ensure the same $\mathrm{pH}$ levels (7 and 8) for each individual experiment using $4 \mathrm{M} \mathrm{HCl}$ and/ or $\mathrm{NaOH}$ solutions. Specifically, for reactors with $\mathrm{NH}_{4} \mathrm{Cl}$, where the dissociation happened 
154 immediately, $\mathrm{pH}$ adjustment was performed before the incubation started. However, for

155 reactors containing urea and the hydrolysis happened slowly, the $\mathrm{pH}$ was adjusted several

156 times until the hydrolysis finished (the details were provided in the E-supplement file). Finally,

157 all the batch reactors were incubated in their corresponding temperatures $\left(37 \pm 1^{\circ} \mathrm{C}\right.$ for

158 mesophilic and $55 \pm 1^{\circ} \mathrm{C}$ for thermophilic).

159

160

161

162

163

164

\subsection{Analytical methods}

Methane accumulation in the headspace of the batch reactors was determined by a gas chromatographer (Trace 1310 GC-TCD, Thermo Fisher, Denmark) equipped with a TracePLOT TG-BOND Q 26004-6030 column (30 m x 0.32 mm I.D., film thickness $10 \mu \mathrm{m}$ ) (Thermo Fisher), and helium was used as carrier gas (Tian et al., 2017). The $\mathrm{pH}$ of each reactor was measured with PHM99 LAB pH meter (Radiometer TM).

\subsection{Calculations and statistics}

\subsubsection{Free ammonia}

The free ammonia concentration was calculated based on the following equation (Siles et al., 2010):

$$
\mathrm{FAN}=\frac{\mathrm{TAN}}{1+\frac{10^{-\mathrm{pH}}}{\mathrm{K}_{\mathrm{a}}}}
$$

where $\mathrm{K}_{\mathrm{a}}$ is the dissociation constant affected by temperature, which equals to $1.29 \times 10^{-9}$ and $3.91 \times 10^{-9}$ in this study for mesophilic and thermophilic condition, respectively.

\subsubsection{Methane production inhibition}

The methane production inhibition was defined as the ratio of the difference between theoretical and practical methane production divided by the maximum theoretical methane production. Maximum theoretical production, for the different carbon sources in the medium, was calculated according to Angelidaki et al. (2011) and it was 122,373 and $525 \mathrm{~mL} \mathrm{CH} \cdot \mathrm{g}^{-1}$ 
177 VS for formate, acetate and methanol. Meanwhile, for the $\mathrm{H}_{2} / \mathrm{CO}_{2}$ mixture gas, it was

178 calculated based on that $1 \mathrm{~mL} \mathrm{CH}_{4}$ forms from $4 \mathrm{~mL} \mathrm{H}_{2}$ and $1 \mathrm{~mL} \mathrm{CO}_{2}$.

$179 \quad$ 2.4.3 Maximum specific growth rate

180 Maximum specific growth rate $\left(\mu_{\max }\right)$ was calculated through the OriginLab program

181 (OriginLab Corporation, Northampton, Massachusetts) by calculating the slope of the linear

182 part of the semi-logarithmic graph of the methane production of the reactors versus time

183 (Gray et al., 2009).

$184 \quad 2.4 .4 \quad$ Statistical analysis

185 The OriginLab program was used for statistical analyses and data plotting. One-way and

186 two-way ANOVA were used to evaluate the statistically differences $(p<0.05)$ of ammonia

187 inhibition under different parameters (e.g. different ammonia sources, ammonia levels and pH

188 levels). Single outliers test was applied to the triplicate measurements if needed.

\section{Results and discussion}

1901 Impact on pH from two different ammonia sources

191 The impact of urea hydrolysis and $\mathrm{NH}_{4} \mathrm{Cl}$ dissociation on $\mathrm{pH}$ was significantly different

192 ( $p<0.05$, Fig. 1). Specifically, after urea hydrolysis completed, except for the basic TAN

193 levels, the $\mathrm{pH}$ increased to around 9 for M. thermophila, M. barkeri, and M. bourgensis,

194 which was outside of the $\mathrm{pH}$ limits (6.5-8.5) for AD process (Lay et al., 1998). This increase

195 in pH after urea hydrolysis, was in agreement with a previous study (Udert et al., 2003) where

196 elevated $\mathrm{pH}$ was observed alongside the extent of urea hydrolysis. The $\mathrm{pH}$ of $M$. thermophilus

197 increased alongside the urea concentration, and it was about 8.5 at the highest TAN level

198 (5000 $\mathrm{mg} \mathrm{NH}_{4}{ }^{+}-\mathrm{N} \cdot \mathrm{L}^{-1}$ ). This different performance of $M$. thermophilus from the other strains

199 could be explained by the stronger buffer capacity in M. thermophilus medium compared to

200 the other media due to the higher $\mathrm{NaHCO}_{3}$ concentration. In contrast, $\mathrm{NH}_{4} \mathrm{Cl}$ dissociation did 
201

202

203

204

205

206

207

208

209

210

211

212

213

214

215

216

217

218

219

220

221

222

223

224

225

not have any significant effect on the $\mathrm{pH}$ of batch reactors, with a maximum $\mathrm{pH}$ drop of approximately 0.3 units at the highest TAN levels $\left(10000 \mathrm{mg} \mathrm{NH}{ }_{4}{ }^{+} \mathrm{N} \cdot \mathrm{L}^{-1}\right)$. Therefore, it seems that $\mathrm{NH}_{4} \mathrm{Cl}$ is not a representative ammonia source to simulate ammonia inhibition in $\mathrm{AD}$ reactors because, contrary to urea, it does not have an analogous $\mathrm{pH}$ effect.

Meanwhile, it also can be seen that a medium with strong buffer capacity could mitigate the effect of urea hydrolysis on $\mathrm{pH}$ (e.g. M. thermophilus case); thus, it is reasonable to suspect that the $\mathrm{pH}$ of manure-based $\mathrm{AD}$ reactors (high buffer capacity) would not increase in such a great extent. At the same time, without $\mathrm{pH}$ adjustment, the pure strains are not expected to grow with urea (except in the basic TAN concentrations), due to the unfavourable pH levels (> 8.5). Therefore, all the following methanogenesis batch experiments in assay II, were designed with a $\mathrm{pH}$ adjustment strategy (adjust the initial $\mathrm{pH}$ level to 7 and 8 , respectively) to compare the effect of the two different ammonia sources on the pure methanogenic strains, independently of the $\mathrm{pH}$.

\subsection{Methanogenesis performance of different methanogens}

\subsubsection{Aceticlastic M. thermophile and M. barkeri}

Urea had similar or significantly higher $(p<0.05)$ inhibitory effect on both aceticlastic strains compared to $\mathrm{NH}_{4} \mathrm{Cl}$ in the majority of the tested TAN levels. For example, $\mathrm{NH}_{4} \mathrm{Cl}$ inhibited the methane production of $M$. thermophila by $58 \%$ at $5000 \mathrm{mg} \mathrm{NH}{ }_{4}{ }^{+}-\mathrm{N} \cdot \mathrm{L}^{-1}(\mathrm{pH}=8)$; at the same time, urea inhibited the same strain more than $90 \%$ at $5000 \mathrm{mg} \mathrm{NH}{ }^{+}-\mathrm{N} \cdot \mathrm{L}^{-1}$ for $\mathrm{pH}=7$ and at all TAN levels above $3000 \mathrm{mg} \mathrm{NH}_{4}{ }^{+}-\mathrm{N} \cdot \mathrm{L}^{-1}$ for $\mathrm{pH}=8$ (Fig. 2a). The different inhibition effects were also reflected on the longer lag phases at the same ammonia levels for urea compared to $\mathrm{NH}_{4} \mathrm{Cl}$. To be specific, up to threefold longer lag phase periods were in urea reactors compared to $\mathrm{NH}_{4} \mathrm{Cl}$ reactors (Table 3). Furthermore, at lower FAN levels $(<151 \mathrm{mg}$ $\left.\mathrm{NH}_{3}-\mathrm{N} \cdot \mathrm{L}^{-1}\right), \mu_{\max }$ of $M$. thermophila was between $0.04-0.06 \mathrm{~h}^{-1}$ for both urea and $\mathrm{NH}_{4} \mathrm{Cl}$ reactors coinciding with $\mu_{\max }$ values reported before (Sowers et al., 1984; Mladenovska and 
Ahring, 2000). However, $\mathrm{NH}_{4} \mathrm{Cl}$ reactors had significantly higher $\mu_{\max }$ compared to urea reactor for FAN levels above $151 \mathrm{mg} \mathrm{NH}-\mathrm{N} \cdot \mathrm{L}^{-1}$, which indicates a stronger inhibitory effect of urea (Fig. 2c).

M. barkeri was the most sensitive methanogenic strain to ammonia compared to all the other tested strains. Almost 100\% inhibition was observed at $64\left(5000 \mathrm{mg} \mathrm{NH}_{4}{ }^{+}-\mathrm{N} \cdot \mathrm{L}^{-1}, \mathrm{pH}=7\right)$ and $89 \mathrm{mg} \mathrm{NH} \mathrm{N}_{3}-\mathrm{N} \cdot \mathrm{L}^{-1}\left(7000 \mathrm{mg} \mathrm{NN_{4 }}{ }^{+}-\mathrm{N} \cdot \mathrm{L}^{-1}, \mathrm{pH}=7\right.$ ) for reactors with urea and with $\mathrm{NH}_{4} \mathrm{Cl}$, respectively (Fig.2b). These results were in accordance to previous studies reporting $50 \%$ inhibition of $M$. barkeri growth at $42 \mathrm{mg} \mathrm{NH}-\mathrm{N} \cdot \mathrm{L}^{-1}$ and more than $95 \%$ inhibition at $88 \mathrm{mg}$ $\mathrm{NH}_{3}-\mathrm{N} \cdot \mathrm{L}^{-1}$ (Sprott and Patel, 1986; Hajarnis and Ranade, 1993). However, although complete inhibition occurred in most ammonia levels, for FAN levels lower than $64 \mathrm{mg} \mathrm{NH}-\mathrm{N} \cdot \mathrm{L}^{-1}$, where methanogenesis was observed, urea was clearly stronger inhibitor than $\mathrm{NH}_{4} \mathrm{Cl}$.

Furthermore, urea prolonged the lag phase up to fourfold compared to $\mathrm{NH}_{4} \mathrm{Cl}$ (Table 3). Even though $M$. barkeri was the most sensitive methanogenic strain tested in the present study, it had the highest $\mu_{\max }$ of $0.11-0.12 \mathrm{~h}^{-1}$ (optimal conditions), which decreased alongside with the increase of ammonia levels (Fig. 2d). Similar specific growth rates $\left(0.10-0.14 \mathrm{~h}^{-1}\right)$ of $M$. barkeri were reported by Jarrell et al. (1987) when TAN was below $1.4 \mathrm{NH}_{4}{ }^{+}-\mathrm{N} \cdot \mathrm{L}^{-1}$, and more than $50 \%$ reduction was detected around $4 \mathrm{NH}_{4}{ }^{+}-\mathrm{N} \cdot \mathrm{L}^{-1}$. However, no significant difference ( $p>0.05$ ) of the $\mu_{\max }$ can be found between urea and $\mathrm{NH}_{4} \mathrm{Cl}$ reactors.

\subsubsection{Hydrogenotrophic M. thermophilus and M. bourgensis}

Overall, hydrogenotrophic methanogens were, as expected (Werner et al., 2014), more tolerant to $\mathrm{NH}_{4} \mathrm{Cl}$ than the aceticlastic methanogens tested in the current study. Interestingly, it was also found that hydrogenotrophic methanogens were more tolerant to urea than aceticlastic methanogens. Nevertheless, similar to aceticlastic strains, urea also had a higher inhibitory effect on the hydrogenotrophic methanogens compared to $\mathrm{NH}_{4} \mathrm{Cl}$. However, there was an exception for $M$. thermophilus at low TAN levels $\left(<3000 \mathrm{mg} \mathrm{NH}_{4}{ }^{+}-\mathrm{N} \cdot \mathrm{L}^{-1}\right)$, where 
$\mathrm{NH}_{4} \mathrm{Cl}$ seemed to be more toxic than urea (Fig. 3a). The reasons might be firstly, the $\mathrm{pH}$ of

252 the urea reactors did not increase due to the strong buffer capacity of $M$. thermophilus medium as discussed previously; Secondly, $\mathrm{NH}_{4} \mathrm{Cl}$ reactors suffered higher toxicity than urea reactors at the beginning because of the higher ammonia concentration from instant $\mathrm{NH}_{4} \mathrm{Cl}$ dissociation compared to from the gradual urea hydrolysis process. However, at higher TAN levels (> $\left.3000 \mathrm{mg} \mathrm{NH}_{4}{ }^{+}-\mathrm{N} \cdot \mathrm{L}^{-1}\right)$, urea inhibited M. thermophilus significantly stronger $(p<0.05)$ than $\mathrm{NH}_{4} \mathrm{Cl}$. All the M. thermophilus reactors had a lag phase smaller than 1.2 days (Table 4) maintaining a $\mu_{\max }$ between $0.03-0.04 \mathrm{~h}^{-1}$ indicating that $M$. thermophilus was able to cope 259 with the strong ammonia toxicity. This was in agreement with Wang et al. (2015) reporting no 260 significant drop $(p>0.05)$ on methane production at ammonia levels up to $7000 \mathrm{mg} \mathrm{NH}{ }_{4}{ }^{+}-\mathrm{N} \cdot \mathrm{L}^{-}$ $261{ }^{1}$ for M. thermophilus with a $\mu_{\max }$ around $0.03 \mathrm{~h}^{-1}$.

262 M. bourgensis was the most ammonia tolerant methanogenic strain tested in the current 263 study, in which no more than $15 \%$ inhibition was observed, and independently of the 264 ammonia sources, ammonia levels and pH levels (Fig.3b). This high tolerance was expected 265 because $M$. bourgensis was reported (Fotidis et al., 2014) to thrive under high ammonia levels 266 (5000 $\mathrm{mg} \mathrm{NH}_{4}{ }^{+}-\mathrm{N} \mathrm{L}^{-1}$ ). Moreover, Westerholm et al. (2015) observed that M. bourgensis was 267 the dominant archaeon in AD reactors operated under high FAN levels $\left(900 \mathrm{mg} \mathrm{NH}-\mathrm{N} \cdot \mathrm{L}^{-1}\right)$, 268 and Wang et al. (2015) also demonstrated that M. bourgensis can work properly at TAN 269 levels up to $7000 \mathrm{mg} \mathrm{NH}{ }_{4}{ }^{+} \mathrm{N} \cdot \mathrm{L}^{-1}$. However, even with this tolerant methanogen, urea was 270 proven more toxic than $\mathrm{NH}_{4} \mathrm{Cl}$, resulting in lag phases up to ten days for TAN levels above $2715000 \mathrm{mg} \mathrm{NH}{ }_{4}{ }^{+} \mathrm{N} \cdot \mathrm{L}^{-1}$ (pH 8), compared to only two days lag phase for the $\mathrm{NH}_{4} \mathrm{Cl}$ at the 272 highest TAN levels. The same trend was observed among the specific growth rates, with 273 significantly lower $\mu_{\max }$ for the urea reactors compared to $\mathrm{NH}_{4} \mathrm{Cl}$ reactors in majority of the 274 tested ammonia levels. 


\section{The ammonia sources and the inhibition mechanism}

In general, urea was a significantly stronger inhibitor than $\mathrm{NH}_{4} \mathrm{Cl}$ (Table 5). This could be explained by the different manners that urea and $\mathrm{NH}_{4} \mathrm{Cl}$ introduce TAN and FAN into the reactors. Specifically, $\mathrm{NH}_{4} \mathrm{Cl}$, as an easily soluble salt, can fully dissociate in aqueous phase immediately after its addition and the direct dissociative products are ammonium ions (Eq. 2), instead of the more toxic FAN form (Massé et al., 2014). On the contrary, urea, which is an organic compound, can only be hydrolysed slowly with the presence of urease, and produce directly FAN (Eq. (3)), which is the most toxic ammonia form (Zimmer, 2000). Therefore, relatively high FAN levels develop instantly after urea hydrolysis, before the final $\mathrm{NH}_{4}{ }^{+} \Leftrightarrow \mathrm{NH}_{3}$ equilibrium (Eq. 1) is established, driven by the $\mathrm{pH}$ and the temperature (Emerson et al., 1975). Compared to low FAN levels after $\mathrm{NH}_{4} \mathrm{Cl}$ dissociation, this momentary exposure of the methanogenic cells to such high FAN concentrations after urea hydrolysis, could have a greater impact in their metabolic activity. Furthermore, $\mathrm{NH}_{4} \mathrm{Cl}$ dissociation does not have a significant effect on the $\mathrm{pH}$ of the reactor and thus does not create unfavourable $\mathrm{pH}$ conditions for the methanogens. On contrary, urea hydrolysis without $\mathrm{pH}$ control could increase the $\mathrm{pH}$ of the reactor into unfavourable levels. Even though $\mathrm{pH}$ was adjusted constantly in the current experiment, until the hydrolysis of urea was completed, it was impossible to avoid a temporal $\mathrm{pH}$ increase during the urea hydrolysis period (details are provided in the E-supplement file). Thus the combined effect of momentary high FAN concentrations and $\mathrm{pH}$ increase, even for short time periods during the hydrolysis phase, is proposed as the main mechanism for the stronger inhibitory effect of urea compared to $\mathrm{NH}_{4} \mathrm{Cl}$ on the pure methanogenic strains tested in this study.

\section{Conclusions}

The current study demonstrated that urea was significantly more toxic compared to $\mathrm{NH}_{4} \mathrm{Cl}$ during $\mathrm{AD}$ process. Furthermore, urea hydrolysis resulted in a great $\mathrm{pH}$ increase to 
300

301

302

303

304

305

306

307

308

309

310

311

312

313

314

315

316

317

318

319

320

unfavourable levels for methanogenic growth. However, a high buffer capacity can mitigate the $\mathrm{pH}$ increase and lower the ammonia toxicity from urea. Additionally, hydrogenotrophic methanogens were more tolerant, not only to $\mathrm{NH}_{4} \mathrm{Cl}$ but also to urea, compared to aceticlastic methanogens. Finally, considering only pure strains were tested in this study, further studies in a more complex environment of real AD digesters are still needed to analyse the inhibition effect of urea.

\section{Appendix A. Supplementary material}

E-supplementary data for this work can be found in e-version of this paper online: Fig. S1. Preliminary urea hydrolysis test at different ammonia and $\mathrm{pH}$ levels with/ without urease under two different incubation temperatures, a) for thermophilic $M$. thermophila and b) for mesophilic M. bourgensis. Fig. S2. pH adjustment strategies to 7 and 8 at different urea concentrations for a) M. thermophila, b) M. barkeri, c) M. thermophilus, d) M. bourgensis

\section{Acknowledgements}

This work was supported by Energinet.dk under the project framework ForskEL

"MicrobStopNH $\mathrm{N}_{3}$-Innoyative bioaugmentation strategies to tackle ammonia inhibition in anaerobic digestion process" (program no. 2015-12327). Hailin Tian would like to thank for the financial support from China Scholarship Council, and Konstantinos Kissas thanks

Alexander S. Onassis Public Benefit Foundation for granting a scholarship. The authors thank Hector Garcia for his technical support during the experiments.

\section{References}

[1] Angelidaki, I., Ahring, B., 1993. Thermophilic anaerobic digestion of livestock waste: the effect of ammonia. Appl. Microbiol. Biotechnol. 38, 560-564.

[2] Angelidaki, I., Karakashev, D., Batstone, D.J., Plugge, C.M., Stams, A.J., 2011. Biomethanation and its potential. Methods Enzymol. 494, 327-51. 
[3] Calli, B., Mertoglu, B., Inanc, B., Yenigun, O., 2005. Methanogenic diversity in anaerobic bioreactors under extremely high ammonia levels. Enzyme Microb. Technol. 37, 448455.

[4] Chen, H., Wang, W., Xue, L., Chen, C., Liu, G., Zhang, R., 2016. Effects of Ammonia on Anaerobic Digestion of Food Waste: Process Performance and Microbial Community. Energy Fuels 30, 5749-5757.

[5] Chen, Y., Cheng, J.J., Creamer, K.S., 2008. Inhibition of anaerobic digestion process: a review. Bioresour. Technol. 99, 4044-64.

[6] Chynoweth, D.P., Owens, J.M., Legrand, R., 2001. Renewable methane from anaerobic digestion of biomass. Renewable Energy 22, 1-8.

[7] Ciurli, S., Benini, S., Rypniewski, W.R., Wilson, K.S., Miletti, S., Mangani, S., 1999. Structural properties of the nickel ions in urease: novel insights into the catalytic and inhibition mechanisms. Coord. Chem. Rev. 190, 331-355.

[8] Cuetos, M.J., Gómez, X., Otero, M., Morán, A., 2008. Anaerobic digestion of solid slaughterhouse waste (SHW) at laboratory scale: Influence of co-digestion with the organic fraction of municipal solid waste (OFMSW). Biochem. Eng. J. 40, 99-106.

[9] Dai, X., Hu, C., Zhang, D., Dai, L., Duan, N., 2017. Impact of a high ammoniaammonium-pH system on methane-producing archaea and sulfate-reducing bacteria in mesophilic anaerobic digestion. Bioresour. Technol. 245, 598-605.

[10] DSMZ. 2014a. 120. Methanosarcina medium, Leibniz-Institut DSMZ- Deutsche Sammlung von Mikroorganismen und Zellkulturen GmbH. German.

[11] DSMZ. 2014b. 120a. Methanosarcina barkeri medium, Leibniz-Institut DSMZ Deutsche Sammlung von Mikroorganismen und Zellkulturen GmbH.

[12] DSMZ. 2017. 141. Methanogenium medium $\left(\mathrm{H}_{2} / \mathrm{CO}_{2}\right)$, Leibniz-Institut DSMZ Deutsche Sammlung von Mikroorganismen und Zellkulturen GmbH. 
[13] DSMZ. 2014c. 332. Methanogenium bourgense medium, Leibniz-Institut DSMZ Deutsche Sammlung von Mikroorganismen und Zellkulturen GmbH.

[14] Emerson, K., Russo, R.C., Lund, R.E., Thurston, R.V., 1975. Aqueous Ammonia Equilibrium Calculations: Effect of $\mathrm{pH}$ and Temperature. J. Fish. Res. Board Can. 32, 2379-2383.

[15] Fotidis, I.A., Wang, H., Fiedel, N.R., Luo, G., Karakashev, D.B., Angelidaki, I., 2014. Bioaugmentation as a solution to increase methane production from an ammonia-rich substrate. Environ. Sci. Technol. 48, 7669-76.

[16] Gray, N.D., Sherry, A., Larter, S.R., Erdmann, M., Leyris, J., Liengen, T., Beeder, J., Head, I.M., 2009. Biogenic methane production in formation waters from a large gas field in the North Sea. Extremophiles 13, 511-9.

[17] Hajarnis, S.R., Ranade, D.R., 1993. Revival of ammonia inhibited cultures of Methanobacterium bryantii and Methanosarcina barkeri. J. Ferment. Bioeng. 76, 70-72.

[18] Holm-Nielsen, J.B., Al Seadi, T., Oleskowicz-Popiel, P., 2009. The future of anaerobic digestion and biogas utilization. Bioresour. Technol. 100, 5478-84.

[19] Jarrell, K.F., Saulnier, M., Ley, A., 1987. Inhibition of methanogenesis in pure cultures by ammonia, fatty acids, and heavy metals, and protection against heavy metal toxicity by sewage sludge. Can. J. Microbiol. 33, 551-554.

[20] Karakashev, D., Batstone, D.J., Angelidaki, I., 2005. Influence of environmental conditions on methanogenic compositions in anaerobic biogas reactors. Appl. Environ. Microbiol. 71, 331-8.

370 [21] Krajewska, B., 2009. Ureases I. Functional, catalytic and kinetic properties: A review. J. Mol. Catal. B: Enzym. 59, 9-21. 
[22] Lay, J.J., Li, Y.Y., Noike, T., 1998. The influence of $\mathrm{pH}$ and ammonia concentration on the methane production in high-solids digestion processes. Water Environ. Res. 70, 1075-1082.

[23] Liu, T., Sung, S., 2002. Ammonia inhibition on thermophilic aceticlastic methanogens. Water Sci. Technol. 45, 113-120.

[24] Massé, D.I., Rajagopal, R., Singh, G., 2014. Technical and operational feasibility of psychrophilic anaerobic digestion biotechnology for processing ammonia-rich waste. Appl. Energy 120, 49-55.

[25] Mladenovska, Z., Ahring, B.K., 2000. Growth kinetics of thermophilic Methanosarcina spp. isolated from full-scale biogas plants treating animal manures. FEMS Microbiol. Ecol. 31, 225-229.

[26] Mobley, H., Island, M.D., Hausinger, R.P., 1995. Molecular biology of microbial ureases. Microbiol. Rev. 59, 451-480.

[27] Møller, H.B., Sommer, S.G., Ahring, B.K., 2004. Biological Degradation and Greenhouse Gas Emissions during Pre-Storage of Liquid Animal Manure. J. Environ. Qual. 33, 27-36.

[28] Rajagopal, R., Massé, D.I., Singh, G., 2013. A critical review on inhibition of anaerobic digestion process by excess ammonia. Bioresour. Technol. 143, 632-641.

[29] Riffat, R., Krongthamchat, K., 2006. Specific methanogenic activity of halophilic and mixed cultures in saline wastewater. Int. J. Environ. Sci. Technol. 2, 291-299.

[30] Schnürer, A., Zellner, G., Svensson, B.H., 1999. Mesophilic syntrophic acetate oxidation during methane formation in biogas reactors. FEMS Microbiol. Ecol. 29, 249-261. 
[31] Siles, J., Brekelmans, J., Martin, M., Chica, A., Martin, A., 2010. Impact of ammonia and sulphate concentration on thermophilic anaerobic digestion. Bioresour. Technol. $101,9040-9048$.

[32] Sowers, K.R., Nelson, M.J., Ferry, J.G., 1984. Growth of acetotrophic, methaneproducing bacteria in a pH auxostat. Curr. Microbiol. 11, 227-229.

[33] Sprott, G.D., Patel, G.B., 1986. Ammonia toxicity in pure cultures of methanogenic bacteria. Syst. Appl. Microbiol. 7, 358-363.

402

[34] Sterling, M., Lacey, R., Engler, C., Ricke, S., 2001. Effects of ammonia nitrogen on H 2 and $\mathrm{CH} 4$ production during anaerobic digestion of dairy cattle manure. Bioresour. Technol. 77, 9-18.

[35] Sung, S., Liu, T., 2003. Ammonia inhibition on thermophilic anaerobic digestion. Chemosphere 53, 43-52.

[36] Tian, H., Fotidis, I.A., Mancini, E., Angelidaki, I., 2017. Different cultivation methods to acclimatise ammonia-tolerant methanogenic consortia. Bioresour. Technol. 232, 1-9.

[37] Udert, K.M., Larsen, T.A., Biebow, M., Gujer, W., 2003. Urea hydrolysis and precipitation dynamics in a urine-collecting system. Water Res. 37, 2571-2582.

411 [38] Viana, M.B., Freitas, A.V., Leitão, R.C., Pinto, G.A.S., Santaella, S.T., 2012. Anaerobic digestion of crude glycerol: a review. Environ. Technol. Rev. 1, 81-92.

413 [39] Wang, H., Fotidis, I.A., Angelidaki, I., 2015. Ammonia effect on hydrogenotrophic 414 methanogens and syntrophic acetate-oxidizing bacteria. FEMS Microbiol. Ecol. 91. 415 [40] Werner, J.J., Garcia, M.L., Perkins, S.D., Yarasheski, K.E., Smith, S.R., Muegge, B.D., Stadermann, F.J., DeRito, C.M., Floss, C., Madsen, E.L., 2014. Microbial community dynamics and stability during an ammonia-induced shift to syntrophic acetate oxidation. Appl. Environ. Microbiol. 80, 3375-3383. 
419 [41] Westerholm, M., Leven, L., Schnurer, A., 2012. Bioaugmentation of syntrophic acetate-oxidizing culture in biogas reactors exposed to increasing levels of ammonia. Appl. Environ. Microbiol. 78, 7619-25.

[42] Westerholm, M., Müller, B., Isaksson, S., Schnürer, A., 2015. Trace element and temperature effects on microbial communities and links to biogas digester performance at high ammonia levels. Biotechnol. Biofuels 8, 154.

[43] Yenigün, O., Demirel, B., 2013. Ammonia inhibition in anaerobic digestion: A review. Process Biochem. 48, 901-911.

[44] Zimmer, M., 2000. Molecular Mechanics Evaluation of the Proposed Mechanisms for the Degradation of Urea by Urease. J. Biomol. Struct. Dyn. 17, 787-797. 
433 Fig. 1. $\mathrm{pH}$ value after the hydrolysis of the urea and the dissolution of the $\mathrm{NH}_{4} \mathrm{Cl}$ at different ammonia levels, a) M. thermophila, b) M. barkeri, c) M. thermophilus, d) M. bourgensis

Fig. 2. Final methane production inhibition and $\mu_{\max }$ of $M$. thermophila and M. barkeri under different ammonia sources, ammonia levels and $\mathrm{pH}$ levels, a) inhibition of $M$. thermophila, b) inhibition of $M$. barkeri, c) $\mu_{\max }$ of $M$. thermophila, d) $\mu_{\max }$ of $M$. barkeri.

Fig. 3. Final methane production inhibition and $\mu_{\max }$ of M. thermophilus and M. bourgensis under different ammonia sources, ammonia levels and $\mathrm{pH}$ levels, a) inhibition of $M$. thermophilus, b) inhibition of $M$. bourgensis, c) $\mu_{\max }$ of $M$. thermophilus, d) $\mu_{\max }$ of $M$. bourgensis. 

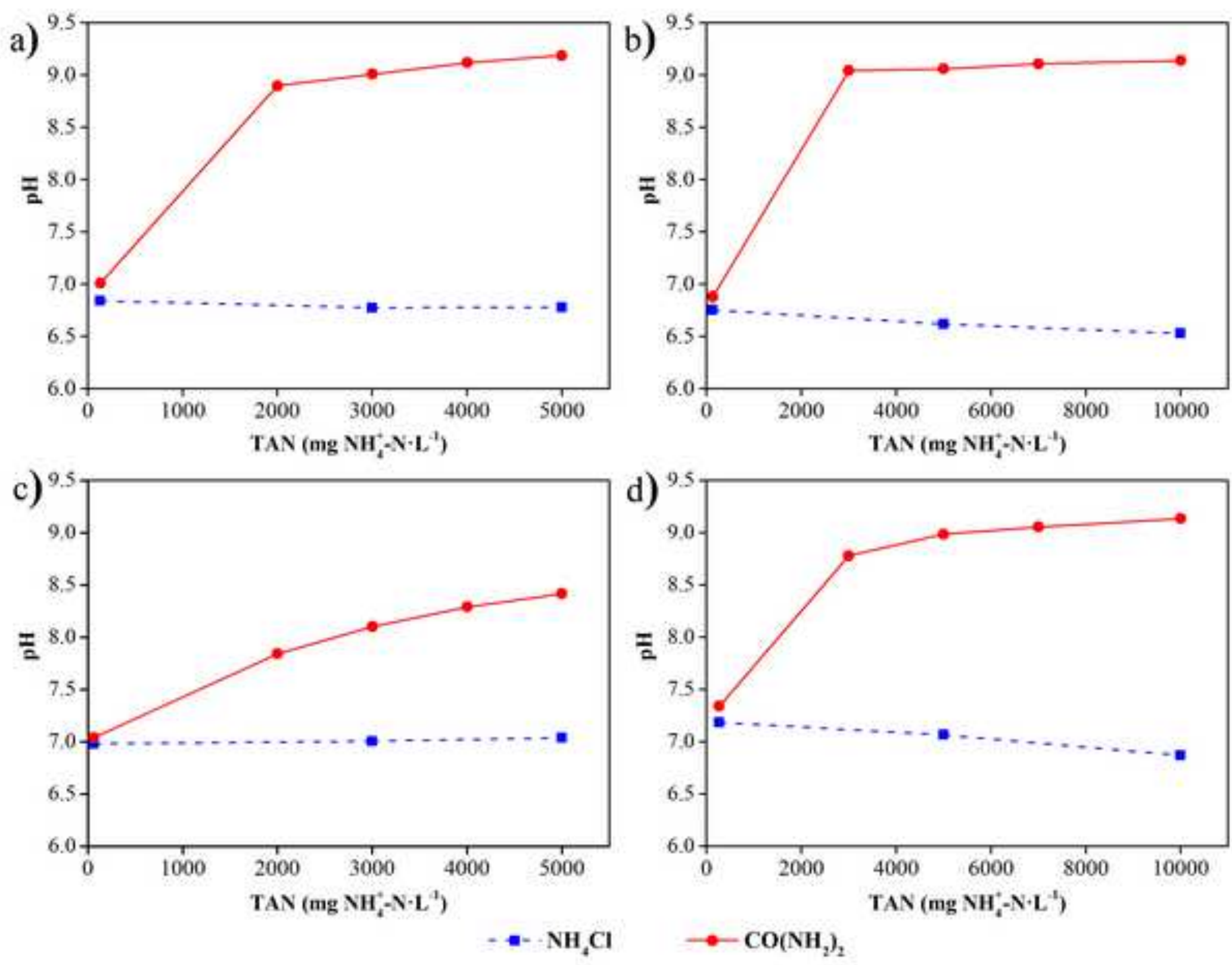


\section{ACCEPTED MANUSCRIPT}
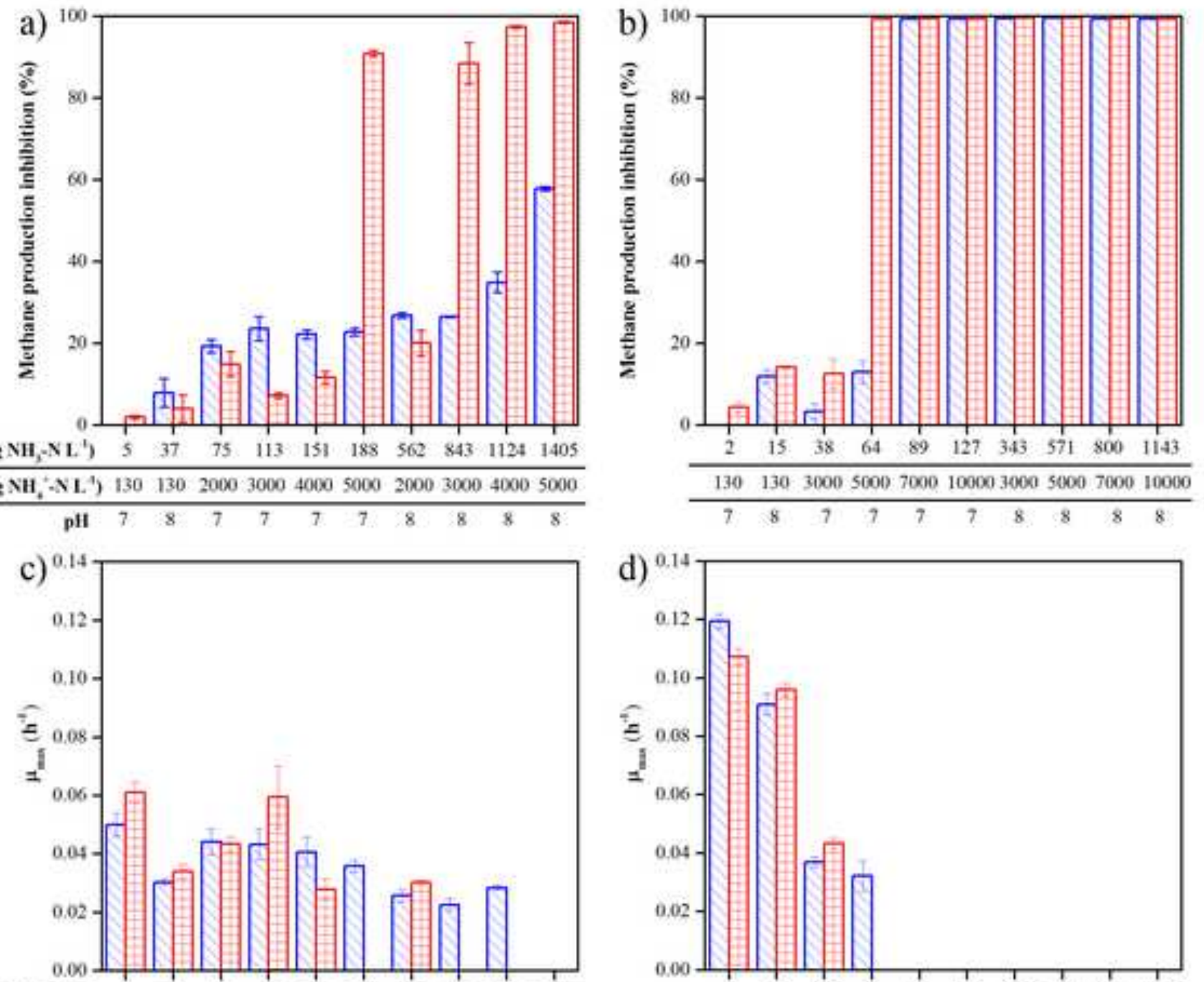

$\begin{array}{llllllllllll}\text { FAN }\left(\operatorname{mg} \mathrm{NII}_{3}-\mathrm{NL}^{\prime}\right) & 5 & 37 & 75 & 113 & 151 & 188 & 562 & 843 & 1124 & 1405\end{array}$

TAN (mg NH ${ }_{4}^{*}$-N L') $130 \quad 130 \quad 2000 \quad 3000 \quad 4000 \quad 5000 \quad 2000 \quad 3000 \quad 4000 \quad 5000$

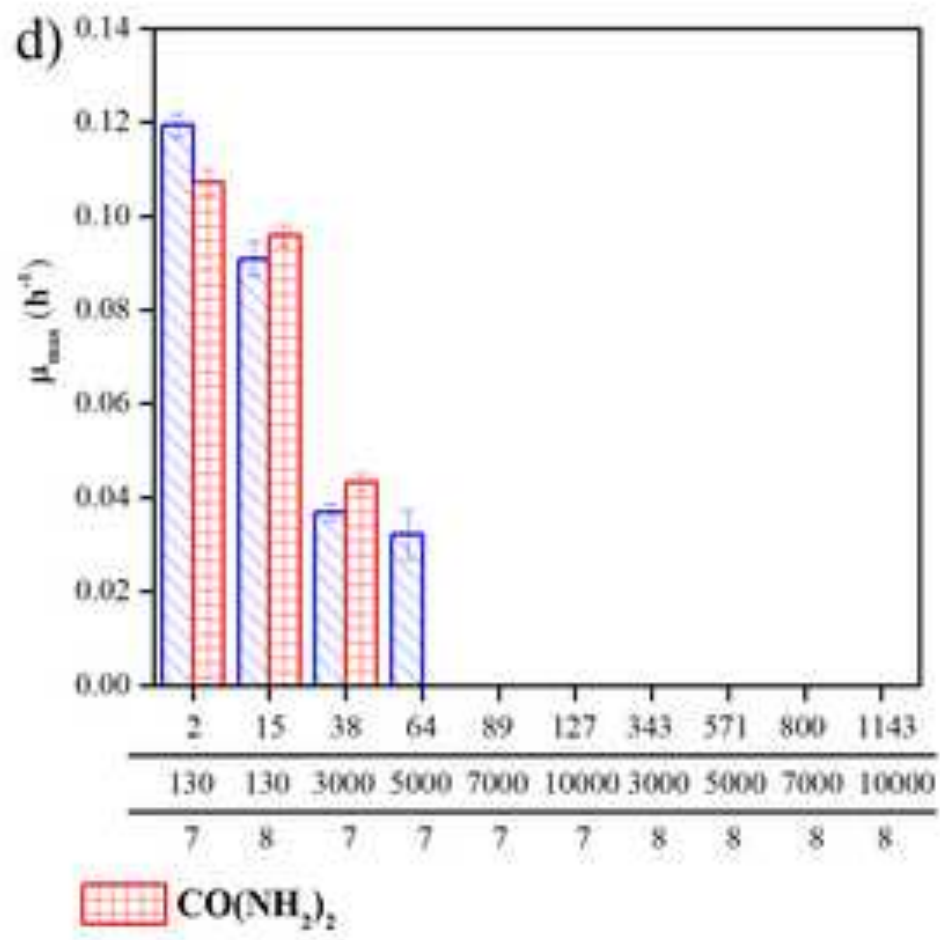


ACCEPTED MANUSCRIPT
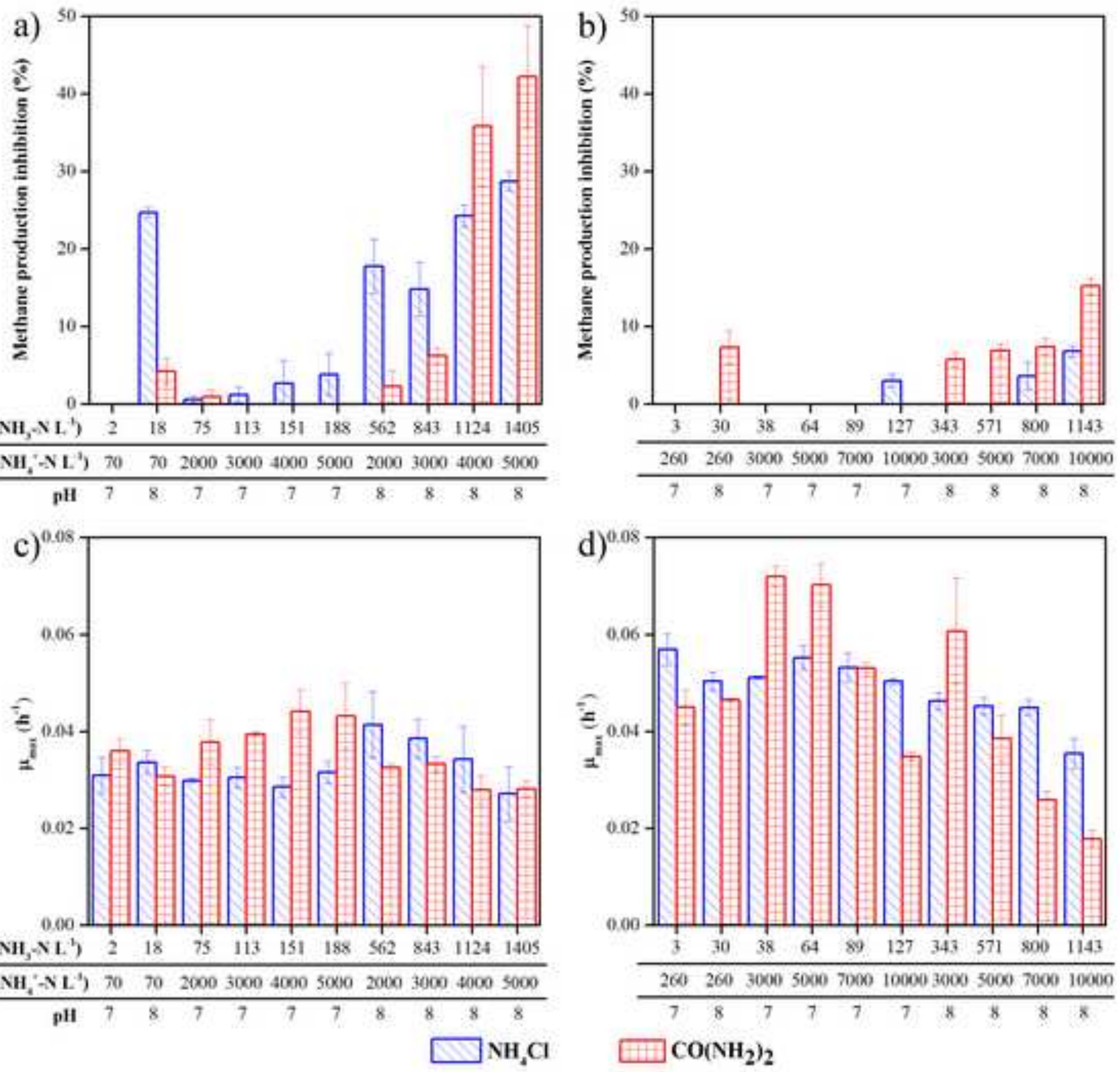
445 Table 1. Different ammonia levels for the two ammonia sources in Assay I.

\begin{tabular}{lll}
\hline Strains & Ammonia sources & TAN $\left(\mathbf{m g ~ N H} \mathbf{~}_{\mathbf{+}}{ }^{+} \mathbf{N} \cdot \mathbf{L}^{-1}\right) *$ \\
\hline M. thermophila & $\mathrm{CO}\left(\mathrm{NH}_{2}\right)_{2}$ & $130,2000,3000,4000$ and 5000 \\
& $\mathrm{NH}_{4} \mathrm{Cl}$ & 130,3000 and 5000 \\
M. barkeri & $\mathrm{CO}\left(\mathrm{NH}_{2}\right)_{2}$ & $130,3000,5000,7000$ and 10000 \\
& $\mathrm{NH}_{4} \mathrm{Cl}$ & 130,5000 and 10000 \\
M. thermophilus & $\mathrm{CO}\left(\mathrm{NH}_{2}\right)_{2}$ & $70,2000,3000,4000$ and 5000 \\
& $\mathrm{NH}_{4} \mathrm{Cl}$ & 70,3000 and 5000 \\
M. bourgensis & $\mathrm{CO}\left(\mathrm{NH}_{2}\right)_{2}$ & $260,3000,5000,7000$ and 10000 \\
& $\mathrm{NH}_{4} \mathrm{Cl}$ & 260,5000 and 10000 \\
\hline
\end{tabular}


448 Table 2. Different ammonia and $\mathrm{pH}$ levels under the two different ammonia sources of Assay 449 II.

\begin{tabular}{lllc}
\hline Strains & TAN $\left(\mathbf{m g ~ N H} \mathbf{~ N H}^{+} \mathbf{-} \cdot \mathbf{L}^{-1}\right) *$ & Ammonia sources & pH levels \\
\hline M. thermophila & $130,2000,3000,4000$ and 5000 & $\mathrm{NH}_{4} \mathrm{Cl}, \mathrm{CO}\left(\mathrm{NH}_{2}\right)_{2}$ & 7,8 \\
M. barkeri & $130,3000,5000,7000$ and 10000 & $\mathrm{NH}_{4} \mathrm{Cl}, \mathrm{CO}\left(\mathrm{NH}_{2}\right)_{2}$ & 7,8 \\
M. thermophilus & $70,2000,3000,4000$ and 5000 & $\mathrm{NH}_{4} \mathrm{Cl}, \mathrm{CO}\left(\mathrm{NH}_{2}\right)_{2}$ & 7,8 \\
M. bourgensis & $260,3000,5000,7000$ and 10000 & $\mathrm{NH}_{4} \mathrm{Cl}, \mathrm{CO}\left(\mathrm{NH}_{2}\right)_{2}$ & 7,8 \\
\hline
\end{tabular}


452 Table 3. Lag phase (days) of $M$. thermophila and $M$. barkeri under different experimental 453 conditions.

\begin{tabular}{|c|c|c|c|c|c|c|c|}
\hline \multirow[t]{3}{*}{ Strains } & \multirow{3}{*}{$\begin{array}{l}\text { Ammonia } \\
\text { sources }\end{array}$} & \multirow[t]{3}{*}{$\overline{\mathbf{p H}}$} & \multicolumn{3}{|c|}{ TAN levels $\left(\mathrm{mg} \mathrm{NH}_{4}{ }^{+}-\mathrm{N} \cdot \mathrm{L}^{-1}\right)$} & \multirow[b]{2}{*}{4000} & \multirow{3}{*}{$\begin{array}{l}5000 \\
(10000)\end{array}$} \\
\hline & & & 130 & 2000 & 3000 & & \\
\hline & & & $(130) *$ & $(3000)$ & $(5000)$ & $(7000)$ & \\
\hline$M$. & $\mathrm{NH}_{4} \mathrm{Cl}$ & 7 & 0 & 0 & 0 & 0 & 0 \\
\hline \multirow[t]{4}{*}{ thermophila } & & 8 & $7.0 \pm$ & $11.0 \pm$ & 17.5 & $32.6 \pm$ & $\mathrm{ND} * *$ \\
\hline & & & 3.0 & 6.2 & & 7.6 & \\
\hline & $\mathrm{CO}\left(\mathrm{NH}_{2}\right)_{2}$ & 7 & 0 & 0 & $3.6 \pm 0.5$ & $4.4 \pm 0.5$ & ND \\
\hline & & 8 & $3.6 \pm$ & $33.0 \pm$ & ND & ND & ND \\
\hline \multirow[t]{6}{*}{ M. barkeri } & $\mathrm{NH}_{4} \mathrm{Cl}$ & 7 & 1.0 & 6.9 & $32.8 \pm$ & ND & ND \\
\hline & & & & & 5.9 & & \\
\hline & & 8 & 0.9 & ND & ND & ND & ND \\
\hline & $\mathrm{CO}\left(\mathrm{NH}_{2}\right)_{2}$ & 7 & 1.1 & $24.8 \pm$ & ND & ND & ND \\
\hline & & & & 8.0 & & & \\
\hline & & 8 & 1.2 & ND & ND & ND & ND \\
\hline
\end{tabular}

454 *Numbers outside parentheses were ammonia concentrations for $M$. thermophila, and the ones inside for $M$.

455 barkeri.

$456 * *$ ND: Not defined. 
459 Table 4. Lag phase (days) of M. thermophilus and M. bourgensis under different experimental 460 situation.

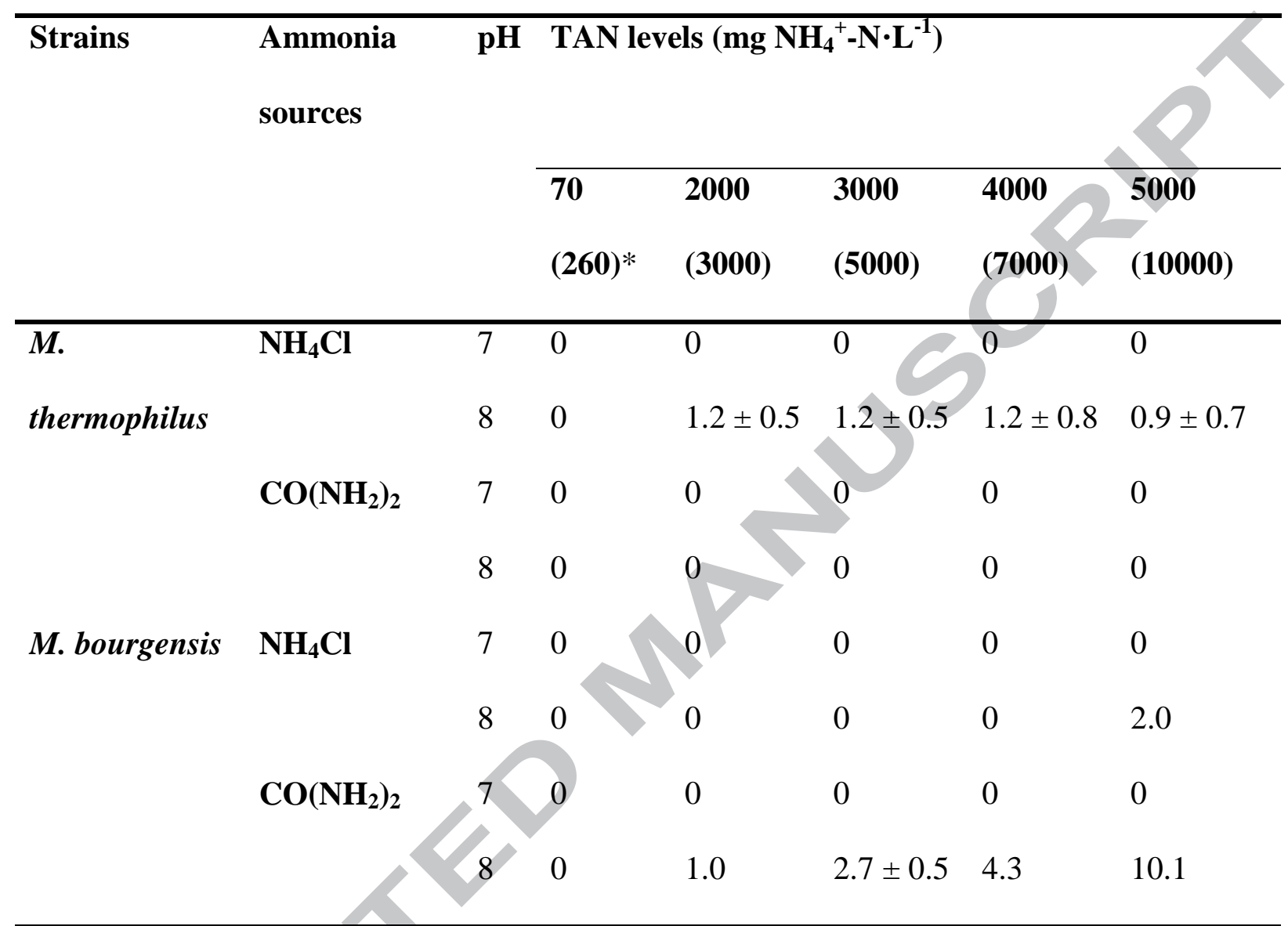

461

*Numbers outside parentheses were the ammonia concentrations for $M$. thermophilus, and the ones inside for $M$. 462 bourgensis.

463 
464 Table 5. Overall comparison of highest methane production inhibition of all strains.

\begin{tabular}{llll}
\hline Strains & $\mathbf{p H}$ & $\mathbf{N H} \mathbf{C l}$ & $\mathbf{C O}\left(\mathbf{N H}_{2}\right)_{2}$ \\
\hline M. thermophila $*$ & 7 & $22.9 \pm 0.9 \%$ & $91.0 \pm 0.8 \%$ \\
& 8 & $57.9 \pm 0.5 \%$ & $98.5 \pm 0.2 \%$ \\
M. barkeri $* *$ & 7 & $99.4 \pm 0 \%$ & $99.4 \pm 0.1 \%$ \\
& 8 & $99.5 \pm 0 \%$ & $99.6 \pm 0.1 \%$ \\
M. thermophilus $*$ & 7 & $3.8 \pm 2.7 \%$ & $0 \%$ \\
& 8 & $28.7 \pm 1.2 \%$ & $42.2 \pm 6.6 \%$ \\
M. bourgensis $*$ & 7 & $3.1 \pm 0.8 \%$ & $28.7 \pm 1.2 \%$ \\
& 8 & $6.8 \pm 0.7 \%$ & $15.2 \pm 1.0 \%$
\end{tabular}

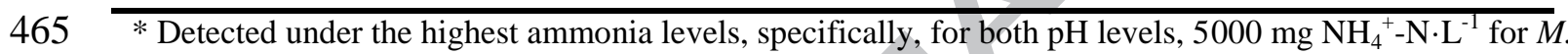

466 thermophila and M. thermophilus, and $10000 \mathrm{mg} \mathrm{NH}_{4}{ }^{+} \mathrm{N} \cdot \mathrm{L}^{-1}$ for $M$. bourgensis.

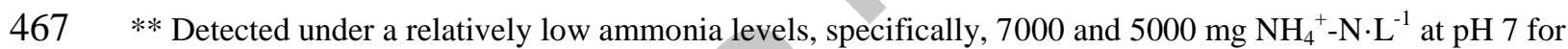

$468 \mathrm{NH}_{4} \mathrm{Cl}$ and urea, respectively, and $3000 \mathrm{mg} \mathrm{NH}_{4}^{+}-\mathrm{N} \cdot \mathrm{L}^{-1}$ at $\mathrm{pH} 8$ for both. 


\section{$470 \quad$ Highlights}

471 - Urea hydrolysis increases reactor $\mathrm{pH}$ significantly more than ammonium chloride

472 - Urea is more toxic to methanogenic archaea than ammonium chloride

473 - Combined high free ammonia and $\mathrm{pH}$ levels is the toxicity mechanism of urea

474 - Hydrogenotrophic methanogens are more robust than aceticlastic methanogens to urea 

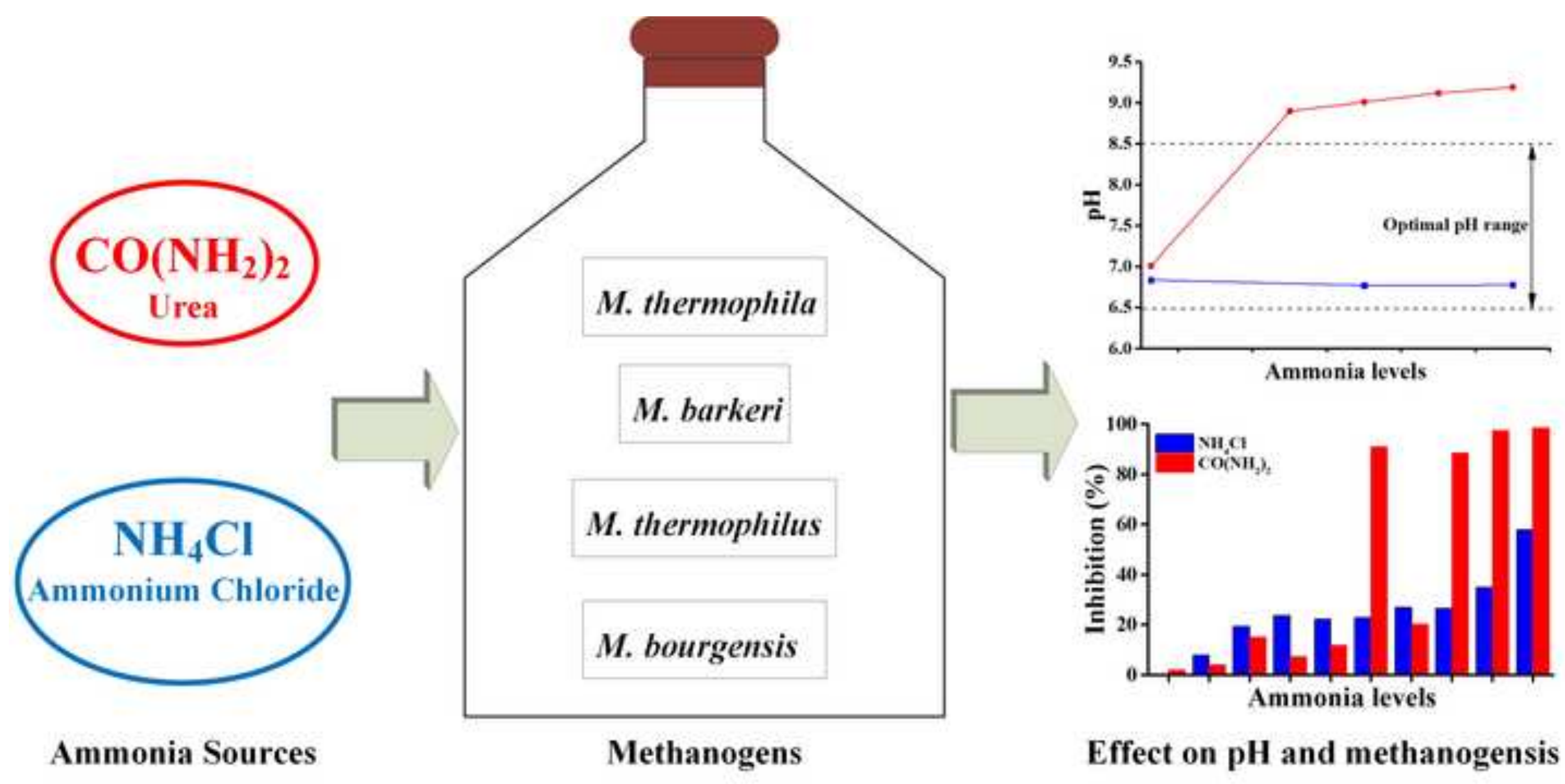

Effect on $\mathrm{pH}$ and methanogensis 